Jurnal Indonesia Sosial Teknologi: p-ISSN: 2723 - 6609

e-ISSN : 2745-5254

Vol. 2, No. 7 Juli 2021

\title{
DAMPAK PANDEMI COVID-19 TERHADAP SEKTOR MODA TRANSPORTASI DARAT (BUS AKAP)
}

\author{
Devi Anggraeni \\ Universitas Darma Persada \\ Email: deviagr03@gmail.com
}

\begin{abstract}
Abstrak
Setahun sudah Indonesia dihadapkan dengan Pandemi Covid-19, kondisi ini jelas menggangu tatanan di semua sektor baik dari sektor perekonomian, pariwisata, maupun sektor-sektor lainnya termasuk moda transportasi darat khususnya penyedia jasa moda transportasi darat. Kebijakan dari pemerintah maupun bisnis yang dilakukan oleh Perusahaan Otobus (PO) dilakukan demi bertahan di masa sulit saat ini. Tulisan ini bertujuan untuk mengetahui bagaimana efektivitas kebijakan yang diberlakukan oleh pemerintah dan optimalisasi strategi Perusahaan Otobus agar bisnis tetap berjalan dengan tetap mengupayakan keamanan dan kenyamanan penumpang. Jenis penelitian ini bersifat deskriptif, metode pengumpulan data menggunakan wawancara terstruktur dan bertahap. Jumlah Responden adalah 20 orang yang terdiri atas pelaku usaha maupun masyarakat sebagai pengguna moda transportasi darat. Hasil yang didapat bahwa perlunya optimalisasi kebijakan yang disesuaikan dengan situasi pandemi saat ini dan perlunya manajemen strategik agar pelayanan yang diberikan dapat melindungi semua aspek baik itu pengguna jasa transportasi darat, pelaku usaha, maupun pemerintah sebagai regulator.
\end{abstract}

Kata Kunci: kebijakan publik; manajemen strategik; pandemi COVID-19

\section{Abstract}

A year ago Indonesia was faced with the Covid-19 pandemic, this condition clearly disrupted the order in all sectors of the economy, tourism, and other sectors including land transportation modes, especially land transportation service providers. Policies from the government and business conducted by the Bus Company $(\mathrm{PO})$ are carried out in order to survive in the current difficult times. This paper aims to find out how effective policies imposed by the government and optimization of the bus company's strategy to keep business running while working for the safety and comfort of passengers. This type of research is descriptive, data collection method using structured and staged interviews. The number of respondents is 20 people consisting of businesses and the public as users of land transportation modes. The results obtained that the need for optimization of policies tailored to the current pandemic situation and the need for strategic management so that the services provided can protect all aspects be it land transportation service users, businesses, and the government as regulators.

Keywords: public policy; strategic management; COVID-19 pandemic 


\section{Pendahuluan}

Pandemi Covid-19 mengancam kesehatan manusia di seluruh dunia. Data menunjukkan Terdapat 154.967 .780 orang di dunia yang terinfeksi virus corona, di Indonesia dengan total 1.691 .658 orang yang terinfeksi virus ini yakni meninggal sebanyak 46.349 orang dan sembuh sebanyak 1.547 .092 orang (https://covid19.go.id/) update terakhir Rabu, 5 Mei 2021. Saat ini pemerintah dan masyarakat dituntut untuk mempersiapkan diri dalam menghadapi situasi darurat dan bertindak responsif dalam mengantisipasi dampak dari covid-19 terhadap sektor bisnis secara keseluruhan, selain itu Covid-19 mulai memperluas penyebarannya kebeberapa sektor termasuk sektor transportasi.

Situasi ini bermula dari anjuran pemerintah untuk tidak melakukan mobilitas di luar rumah dan penerapan atas social distancing atau jaga jarak (Nur Rohim Yunus \&

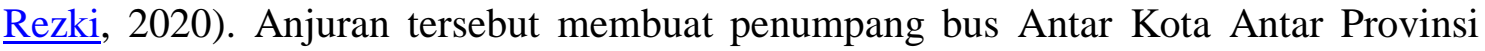
(AKAP) turun drastis sehingga berpengaruh pada Perusahaan Otobus (PO) yang mengalami penurunan pendapatan, dan salah satu PO yang merasakan dampak ini adalah PO Haryanto. Pandemi (COVID-19) yang datang di Indonesia sejak awal 2020 lalu telah memukul dunia transportasi. Seluruh Perusahaan Otobus melakukan berbagai cara untuk mengatasi krisis akibat minimnya penumpang.

Untuk mengatasi permasalahan di atas, dibutuhkan strategi untuk mengembalikan eksistensi pelaku bisnis di sektor transportasi pasca pandemi Covid-19 (Aisyah, 2020). Salah satu strateginya adalah dengan menggunakan analisasis SWOT maupun konsep starategi yang dikemukakan oleh Henry Mintzberg mendefinisikan strategi sebagai 5P yaitu (Plan, Ploy, Pattern, Position and Perspective). Strategi sebagai plan adalah strategi rencana sebelum diimplementasikan dan ditindaklanjuti melalui implementasi. Strategi sebagai ploy adalah aktivitas khusus yang membedakan strategi bisnis pelaku usaha dengan pesaing yang tujuan untuk mengungguli para pesaing. Strategi sebagai pattern menujukkan aktivitas perusahaan yang dapat dijelaskan melalui pola-pola yang muncul dari aktivitas yang telah direncanakan dan dilaksanankan sebelumnya. Strategi sebagai position, yaitu pelaku usaha dapat menggunakan sumber daya yang ada, baik fisik maupun pengetahuan untuk menyediakan produk yang khas menemukan ceruk pasar yang bertujuan menghalangi dan mengungguli pesaing. Terakhir, strategi sebagai perspective mengacu kepada budaya organisasi pada pelaku bisnis untuk memandang dirinya sendiri dan lingkungannnya sebagai sebuah strategi (Fitriyani, Sudiyarti, \& Fietroh, 2020).

Pentingnya manajemen strategi bagi pelaku bisnis di sektor transportasi dapat dilihat dalam beberapa bidang penguatan manajemen yaitu pemasaran, SDM, keuangan dan operasional (Novianto, 2019). Di bidang pemasaran, perlu dikembangkan sistem pemasaran digital yang tepat sasaran dan dapat menjangkau masyarakat luas (Widyaningrum, 2016). Misalnya dengan pemesanan tiket melalui online seperti website, pemesanan melalui pihak kedua (Redbus, Traveloka, Easy Book, dsb.) melakukan promosi melalui media social seperti Facebook, Instagram, Whatsapp atau jejaring sosial yang lain. Sandiasa dan Widnyani, 2017 mengatakan bahwa pada bidang 
penguatan manajemen sumber daya manusia, peningkatan pengetahuan, wawasan dan keterampilan sehingga mampu mengelola usahanya dengan lebih terencana dan terorganisir dengan baik. Penguatan di bidang manajemen keuangan meliputi pengelolaan keuangan yang efektif dan efisien berkaitan dengan akses modal dan administrasi pembukuan/keuangan (Widiastuti \& Santoso, 2017). Terakhir, penguatan di bidang manajemen operasional yang mencakup peningkatan kualitas, efesiensi biaya dan sasaran distribusi yang tepat.

Penelitian ini bertujuan untuk mengetahui bagaimana efektivitas kebijakan yang diberlakukan oleh pemerintah dan optimalisasi strategi Perusahaan Otobus dengan pendekatan analisis SWOT (Strengths, Weaknesses, Opportunities, Threats).

Manajemen merupakan sebuah proses yang terdiri atas perencanaan, pengorganisasian, penggerakan dan pengontrolan guna mencapai tujuan yang telah ditetapkan dengan menggunakan sumber daya manusia dan sumber daya lain. Sejalan dengan teori dari Henry Fayol (Safroni, 2012), "fungsi-fungsi manajemen meliputi Perencanaan (planning), Pengorganisasian (organizing), Pengarahan (commanding), Pengkoordinasian (coordinating), Pengendalian (controlling)". Hal ini juga disampaikan oleh Stoner \& Freeman (Safroni, 2012) yang menjelaskan bahwa manajemen adalah proses perencanaan, pengorganisasian, kepemimpinan, dan pengendalian upaya anggota organisasi dan proses penggunaan semua sumber daya organisasi untuk tercapainya tujuan organisasi yang telah ditetapkan".

Manajemen strategik merupakan serangkaian keputusan dan tindakan manajerial yang menentukan kinerja perusahaan dalam jangka panjang yang meliputi pengamatan lingkungan, perumusan strategi (perencanaan strategis dan perencanaan jangka panjang), implemetasi strategi, dan evaluasi serta pengendalian. Manajemen strategik menekankan pada pengamatan dan evaluasi peluang dan ancaman lingkungan dengan melihat kekuatan dan kelemahan perusahaan (Zulfikar, 2010). (Eddy Yunus, 2016), "manajemen strategis adalah sekumpulan keputusan dan tindakan yang menghasilkan perumusan (formulating) dan pelaksanaan (implementasi) rencana-rencana yang dirancang untuk mencapai sasaran-sasaran perusahaan. Kegiatan manajemen ini melibatkan koordinasi dan mengawasi pekerjaan seseorang sehingga pekerjaannya dapat diselesaikan secara baik dan efisien. Salah satu analisis yang digunakan untuk mengetahui apa saja yang menjadi faktor pendukung dan penghambat dalam pelaksanaan kegiatan pembelajaran yaitu dengan menggunakan analisis SWOT. (Priharto, 2019) menjelaskan bahwa "SWOT adalah singkatan dari Strengths (kekuatan), Weaknessess (kelemahan), Opportunities (kelemahan) dan Threats (ancaman). Dimana Strengths (kekuatan) dan Weaknesses (kelemahan) biasanya berasal dari internal perusahaan sedangkan Opportunities (peluang) dan Threats (ancaman) biasnaya merupakan masalah eksternal yang mempengaruhi bisnis atau hal-hal yang terjadi di luar perusahaan".

Jika berdasarkan pada penjelasan di atas, analisis SWOT ini sangat penting untuk dilakukan, karena pada dasarnya analisis ini bermanfaat untuk dapat mengetahui suatu permasalahan dari empat sisi yang berbeda, yaitu kekuatan, kelemahan, peluang, 
dan ancaman, yang dimilki oleh sebuah perusahaan. Hasil dari suatu analisis ini dapat memberikan rekomendasi untuk meningkatkan kekuatan dan mempertahankan peluang, serta pada saat yang bersamaan mengurangi kelemahan dan dapat menghindari potensi ancaman. Analisis SWOT ini juga berperan sebagai instrumen yang bermanfaat dalam aktivitas analisis strategis. Dengan analisis ini, suatu organisasi dapat meminimalisir kelemahan dan menekan dampak ancaman yang harus dihadapi. Analisis yang diterapkan dengan baik dan dapat dijalankan dengan benar dalam sebuah perusahaan akan sangat membantu untuk dapat melihat sisi-sisi perusahaan yang selama ini tidak terlihat. Tanpa melakukan suatu analisis bisa jadi bisnis yang dibangun tidak berjalan secara efisien dan efektif.

\section{Metode Penelitian}

Penelitian ini menggunakan metode kualitatif dan bersifat deskriptif dengan alat pengumpulan data yaitu wawancara yang mendalam (in deep interview) dan bertahap (Sugiyono, 2017). Wawancara tersebut melalui tatap muka, dan melalui telepon yang masing-masing diwawancarai selama kurang lebih 10 - 15 menit karena mengingat masih berlakunya penerapan social distancing.

Jumlah responden pada penelitian ini sebanyak 20 orang yang terdiri dari 4 orang Driver, 2 orang Helper, 3 orang agen penjualan tiket, 3 orang Busmania, dan 8 orang penumpang yang semuanya di pilih secara acak. Analisis data yang digunakan dalam penelitian adalah berupa deskriptif kualitatif yaitu teknik penelitian yang menggambarkan dan menjelaskan data-data yang telah dikumpulkan dengan memperhatikan dan merekam sebanyak mungkin aspek yang diteliti sehingga mendapatkan gambaran secara menyeluruh tentang kondisi yang sebenarnya (Creswell, 2016). Langkah-langkah analisis data kualitatif pada penelitian ini yaitu: pengumpulan data (data collection), pereduksian data (data reduction), penyajian data (data display), dan penarikan/pemverifikasian simpulan (conclusion drawing/verification).

\section{Hasil dan Pembahasan}

Pada bagian ini, hasil analisis yang didapatkan melalui hasil wawancara yang dilakukan dengan penumpang maupun dengan bismania terkait dengan aspek kebijakan yang dilakukan oleh stakeholders, sebagian besar berpendapat bahwa imbas pemberlakuan pembatasan kegiatan kegiatan masyarakat (PPKM) jelas menyulitkan masyarakat dimana mereka harus membeli tiket dengan harga dua kali lipat dalam sekali jalan karena harus melakukan social distancing dan pernah juga melakukan perjalanan dimana keluar masuk Jakarta masih sangat dibatasi dan harus menggunakan surat izin keluar masuk (SIKM) serta pola perjalanan dari PO Bus yang berubah dimana biasanya bus berangkat pada sore hari menjadi malam hari dengan alasan supaya lolos dari penyekatan.

Kemudian untuk efektivitas dari hasil kebijakan PSBB maupun PPKM didapatkan hasil opini untuk kebijakan tersebut belum $100 \%$ maksimal dikarenakan masyarakat belum melakukan 3M (memakai masker, mencuci tangan, dan menjaga 
jarak) dengan baik. Dan apabila akan melakukan perjalanan dengan bus dapat dipastikan tidak banyak yang mengisi eHAC (electronic Health Alert Card) seperti yang diwajibkan kepada penumpang pesawat. Setelah sampai tujuan pun penumpang masih harus dihadapkan dengan kewajiban untuk melakukan test cepat atau rapid test yang dimana sangat memberatkan dengan alasan adanya biaya tambahan yang harus dikeluarkan dan akhirnya penumpang memilih turun diluar area terminal. Masyarakat berpendapat bahwa seharusnya pemerintah harus menekan biaya test cepat ataupun pilihan lainya dan edukasi sampai dengan tingkat desa tentang test cepat. Didaerah masih banyak stigma yang timbul apabila sesorang terkena covid maka orang itu adalah "pembawa virus" dan akan menularkan virusnya kepada orang lain, sehingga masih banyak orang-orang yang merasa malas bahkan merasa tidak perlu untuk melakukan test.

Pemberlakuan PSBB maupun PPKM bagi pelaku usaha pun membawa efek yang cukup signifikan seperti penurunan pembelian tiket sampai dengan $70 \%$ perharinya. Untuk efektivitas kebijakan pun dirasa belum sepenuhnya efektif karena implementasi yang dilakukan belum dijalankan secara maksimal. Berdasarkan hasil pemaparan wawancara yang dilakukan dapat terlihat bahwa kebijakan yang dilakukan oleh pemerintah untuk mengatasi pandemi Covid 19 seperti Peraturan Pemerintah Republik Indonesia Nomor 21 Tahun 2020 tentang Pembatasan Sosial Berskala Besar Dalam Rangka Percepatan Penanganan Corona Virus Disease 2019 (Covid-19) maupun Peraturan Menteri Kesehatan tentang Pedoman Pembatasan Sosial Berskala Besar Dalam Rangka Percepatan Penanganan Corona Virus Disease 2019 memang merupakan solusi yang ditawarkan oleh pemerintah selaku pemangku kebijakan, namun perlu diingat bahwa Sebaik apapun kebijakan publik yang telah dibuat hanya kan menjadi siasia jika tidak ada upaya untuk mengimplementasikannya karena tidak akan membawa dampak atau tujuan yang diinginkan. Maka dari itu implementasi kebijakan merupakan salah satu tahapan krusial dalam proses kebijakan publik. Masyarakat maupun para pelaku usaha sejatinya menerima apapun hasil kebijakan public tersebut namun sebagian besar berpendapat belum optimalnya kebijakan tersebut dimana mereka mengalami semacam kebingungan karena aturan dengan pelaksanaan dilapangan sedikit banyak membuat masyarakat merasa terbatasi ruang geraknya ditambah kesimpangsiuran mengenai kebijakan yang dibuat pemerintah pusat maupun pemerintah daerah yang pada akhirnya berdampak kepada sektor ekonomi yakni pendapatan PO bus yang menurun drastis yang tentunya berdampak kepada kehidupan para pekerja bahkan yang parahnya agar perusahaan tetap berjalan harus melakukan PHK pegawai.

\section{Manajemen Strategik}

Dari hasil pengumpulan data dengan pelaku usaha didapatkan informasi berupa faktor internal berupa kekuatan dan kelemahan yang dimiliki oleh masing-masing Perusahaan Otobus (PO) dan faktor eksternal berupa peluang dan ancaman yang dihadapi oleh pelaku usaha usaha di masa Pandemi COVID-19. Setelah data 
didapatkan, kemudian dilakukan analisis SWOT untuk mendapatkan 4 alternatif strategi seperti yang terlihat pada tabel berikut:

Tabel 1 : Analisi SWOT

\section{$\begin{array}{llll}\text { Strengh (S) } & \text { Weakness (W) } & \text { Opportunity (O) }\end{array}$}

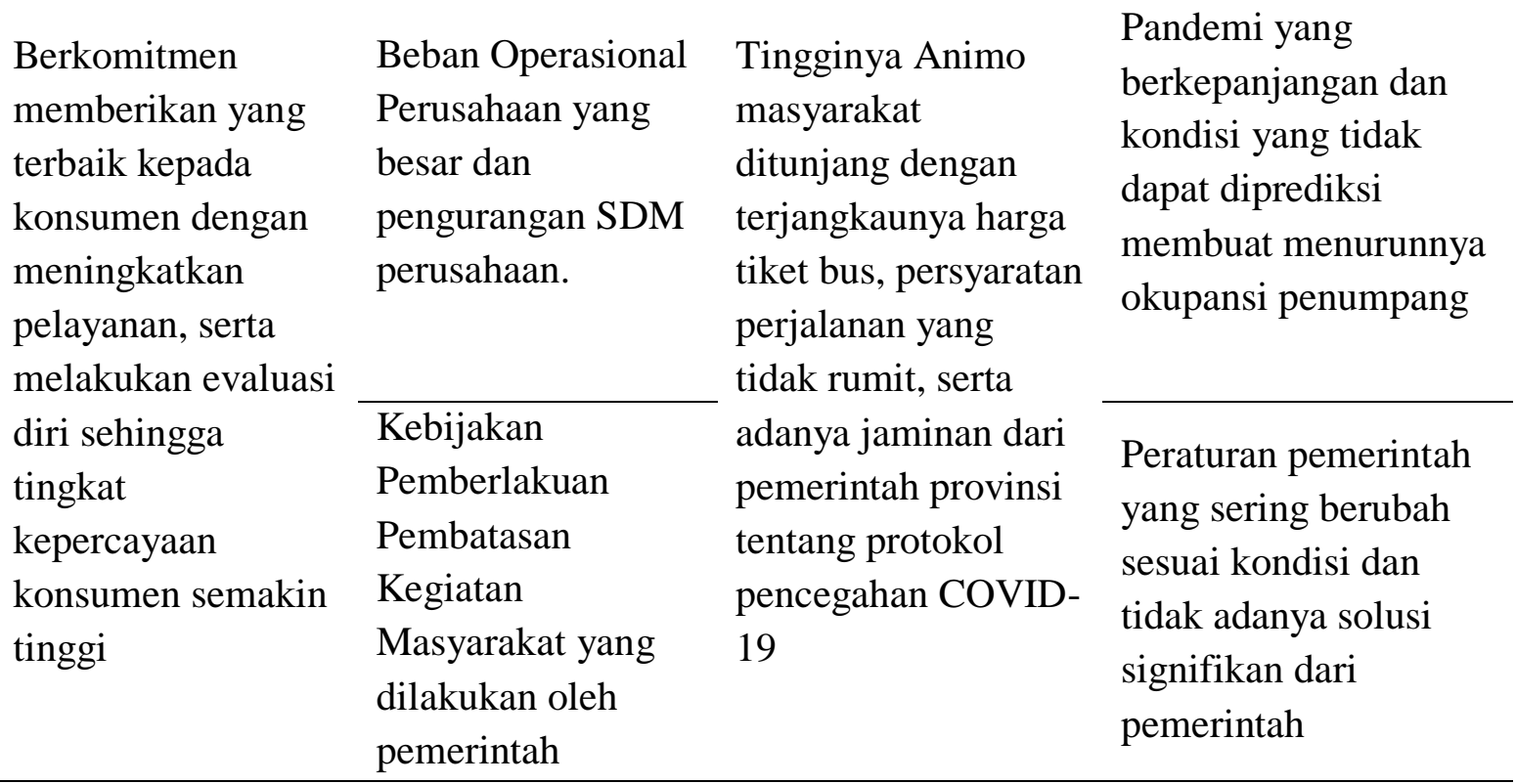

Tabel 2. Strategi SWOT

\begin{tabular}{|c|c|c|c|c|}
\hline Internal & & Strengh (S) & & Weakness $(\mathrm{W})$ \\
\hline Opportunities (O) & 1) & $\begin{array}{l}\text { Tetap menjaga komitmen } \\
\text { perusahaan dalam memberikan } \\
\text { pelayanan terbaik saat kondisi } \\
\text { new normal dan } \\
\text { memanfaatkan peluang } \\
\text { jaminan pemerintah provinsi } \\
\text { tentang protocol pencegahan } \\
\text { COVID-19. } \\
\text { Menjaga Kualitas Pelayanan } \\
\text { untuk dapat mempertahankan } \\
\text { tingkat kepercayaan konsumen } \\
\text { terhadap perusahaan dengan } \\
\text { memanfaatkan kebijakan } \\
\text { pemerintah. } \\
\text { Melakukan evaluasi diri }\end{array}$ & 2) & $\begin{array}{l}\text { Merancang strategi } \\
\text { promosi seperti } \\
\text { memberikan harga khusus } \\
\text { dan memanfaatkan media } \\
\text { online sebagai upaya } \\
\text { branding perusahaan. } \\
\text { Menurunkan Target } \\
\text { Perusahaan menjadi lebih } \\
\text { realistis dengan kondisi } \\
\text { pandemic COVID-19. } \\
\text { Melakukan diversifikasi } \\
\text { usaha dengan cara } \\
\text { merancang paket wisata } \\
\text { minat khusus dengan tetap } \\
\text { mempertimbangkan aspek }\end{array}$ \\
\hline
\end{tabular}




\begin{tabular}{|c|c|c|c|c|}
\hline & 4) & $\begin{array}{l}\text { dengan cara memperbaiki } \\
\text { segala aspek internal } \\
\text { perusahan seperti, manajemen } \\
\text { dan administrasi, cash flow, } \\
\text { produk dan pelayanan. } \\
\text { Menyediakan asuransi } \\
\text { perjalanan dan menambahakan } \\
\text { kegiatan protokol kesehatan ke } \\
\text { dalam SOP pelayanan. } \\
\text { Menciptakan paket wisata } \\
\text { yang diperuntukkan bagi pasar } \\
\text { domestik dan membuat paket } \\
\text { konsorsium dengan relasi } \\
\text { bisnis. } \\
\text { Membuka pelayanan } \\
\text { penjualan tiket secara online } \\
\text { bekerja sama dengan pihak } \\
\text { lain (Redbus, Traveloka, Easy } \\
\text { book, dll) }\end{array}$ & 4) & $\begin{array}{l}\text { kesehatan dalam masa } \\
\text { pandemi COVID-19 dan } \\
\text { membuat paket wisata } \\
\text { virtual. } \\
\text { Melakukan restrukturisasi } \\
\text { manajemen perusahaan } \\
\text { dan mengoptimalkan } \\
\text { SDM yang ada. }\end{array}$ \\
\hline Threat (T) & 1) & $\begin{array}{l}\text { Mengoptimalkan peran Public } \\
\text { Relations untuk meningkatkan } \\
\text { okupansi penumpang dan } \\
\text { sosialisasi mengenai upaya } \\
\text { perusahaan mengedepankan } \\
\text { protokol kesehatan. } \\
\text { Memanfaatkan sumber daya } \\
\text { perusahaan secara optimal } \\
\text { untuk dapat mengatasi } \\
\text { permasalahaan yang ada. } \\
\text { Meningkatkan kualitas SDM } \\
\text { dengan mengikuti berbagai } \\
\text { pelatihan kerja khususnya } \\
\text { bidang pelayanan kepada } \\
\text { customer di masa pandemi } \\
\text { Covid-19. } \\
\text { Memanfaatkan hubungan baik } \\
\text { dengan relasi bisnis dalam } \\
\text { segala hal, termasuk berbagi } \\
\text { informasi terkait kebijakan } \\
\text { pemerintah. }\end{array}$ & $\begin{array}{l}\text { 3) } \\
\text { 4) }\end{array}$ & $\begin{array}{l}\text { Memanfaatkan upaya } \\
\text { meminimalisir dampak } \\
\text { negatif terkait dengan } \\
\text { kebijakan PSBB/PPKM. } \\
\text { Melakukan restrukturisasi } \\
\text { modal usaha dan } \\
\text { mengupayakan untuk } \\
\text { mendapatkan tambahan } \\
\text { modal usaha. } \\
\text { Mengupayakan peluang } \\
\text { pengembangan usaha. } \\
\text { Berupaya terus mengikuti } \\
\text { perkembangan kebijakan } \\
\text { pemerintah. informasi } \\
\text { Memberikan pelatihan- } \\
\text { mengenai dapat } \\
\text { pelatihan yang } \\
\text { diikuti oleh karyawan } \\
\text { dalam rangka peningkatan } \\
\text { kapasitas SDM }\end{array}$ \\
\hline
\end{tabular}




\section{Kesimpulan}

Pandemi covid-19 ini sangat memiliki memiliki banyak dampak baik sosial maupun ekonomi. Dalam hal ini Indonesia telah berupaya untuk mengendalikan dan memutus mata rantai covid-19 dengan membuat dan menerapkan peraturan-peraturan yang berlaku. Namun, dalam menghadapi covid-19 ini, bukan hanya peran pemerintah saja sebagai regulator tetapi diperlukan pencapaian strategi yang matang dan memberikan hasil yang baik pada penguatan manajemen strategik di bidang pemasaran, keuangan, sumber daya manusia dan bidang operasional. Optimisme pelaku usaha untuk bangkit kembali melanjutkan dan meningkatkan usaha mereka dilakukan dari strategi manajemen bisnis. Salah satu cara strategi yang diterapkan yaitu implementasi Analisis SWOT sebagai upaya untuk mampu menciptakan eksistensi bisnis usaha yang lebih efesien dan efektif. Tak kalah pentingnya adalah Perusahaan Otobus (PO) dituntut untuk memiliki manajemen pengetahuan yang baik dan absorptive capacity untuk meningkat kinerja bisnisnya. 
Devi Anggraeni

\section{Bibliografi}

Aisyah, Siti. (2020). Dampak Pandemi Covid-19 Bagi UMKM Serta Strategi EMarketing UMKM Di Indonesia.

Creswell, John W. (2016). Research design: pendekatan metode kualitatif, kuantitatif, dan campuran. Yogyakarta: Pustaka Pelajar, 5.

Fitriyani, Ika, Sudiyarti, Nining, \& Fietroh, M. Nur. (2020). Strategi manajemen bisnis pasca pandemi covid-19. Indonesian Journal of Social Sciences and Humanities, 1(2), 87-95.

Novianto, Efri. (2019). Manajemen Strategis. Deepublish.

Priharto, Sugi. (2019). Analisis SWOT untuk Bisnis. Jakarta: PT Cipta Piranti Sejahtera.

Safroni, Ladzi. (2012). Manajemen dan Reformasi Pelayanan Publik dalam Konteks Birokrasi Indonesia. Surabaya: Aditya Media Publishing.

Sugiyono. (2017). Metode Penelitian Kuantitatif, Kualitatif, dan R\&D. Bandung.

Widiastuti, C. Tri, \& Santoso, Aprih. (2017). Model Manajemen EDU-FINANCE Untuk Meningkatkan Literasi Keuangan Pada UMKM Kayu Kota Semarang. Jurnal Bisnis Dan Ekonomi, 24(2).

Widyaningrum, Premi Wahyu. (2016). Peran media sosial sebagai strategi pemasaran pada sewa kostum Meiyu Aiko Malang. Al Tijarah, 2(2), 230-257.

Yunus, Eddy. (2016). Manajemen Strategis. Penerbit Andi.

Yunus, Nur Rohim, \& Rezki, Annissa. (2020). Kebijakan pemberlakuan lock down sebagai antisipasi penyebaran corona virus Covid-19. Salam: Jurnal Sosial Dan Budaya Syar-I, 7(3), 227-238.

Zulfikar, Rizki. (2010). KONSEP DASAR MANAJEMEN STRATEGI. 